\title{
İtfaiye İstasyonu îhtiyacının Yedek Çift Kapsama Yaklaşımıyla Belirlenmesi ve Yer Seçimi: Trabzon Kenti Örneği
}

\author{
Şeyda Kuku'® ${ }^{1}$, Ersin Türk ${ }^{1 *} \oplus$ \\ ${ }^{1}$ Karadeniz Teknik Üniversitesi, Mimarlık Fakültesi, Şehir ve Bölge Planlama Bölümü, 61080, Trabzon. \\ Özet
}

İtfaiye istasyonlar kentsel alanda can ve mal güvenliğini sağlayan acil hizmet birimleridir. Bu hizmetin ihtiyaca hızl yanıt verecek şekilde yüksek hizmet düzeyi ile sunulması kamu güvenliği açısından çok önemlidir. Ancak, imar mevzuatında itfaiye istasyonlarının planlanmasına yönelik herhangi bir hükme yer verilmediğinden, imar planlarında ve uygulamada itfaiye istasyonlarının sayısına, büyüklüklerine ve konumlarına ilişkin kararlar yetkili belediyenin takdirine bırakılmıştır. Oysa, itfaiye istasyonlarının planlanmasına ilişskin literatür incelendiğinde, tepki süresi, kapsama alanı, nüfus vb. ölçütler dikkate alınarak kent bütününde itfaiye istasyonlarının planlanması önerilmektedir. Bu çalışmanın amacı; Yedek Çift Kapsama yaklaşımıyla, tüm planlama alanına 5 dakika tepki süresi içinde hizmet verilebilecek ve mahallenin yangin risk sinıfina göre literatürdeki 5, 8, 10, 15 dakika erişim süreleri içinde ikinci bir itfaiye istasyonunun yedek kapsamında olacak şekilde en az itfaiye istasyon sayısın ve bu istasyonlara uygun kamusal alanlar yürürlükteki nazım imar planında belirlemektir. Trabzon'un merkez ilçesi Ortahisar imar planı sınırları, çalışma alanı olarak seçilmiştir. Çalışma kent içinde itfaiye istasyonu ihtiyacının belirlenmesine ve yer seçimi sürecine katkı sağlayacaktır. Çalışma sonucunda, var olan itfaiye istasyonun mevcut yerinde kalması gerektiği, kentin doğusunda ve batısında iki itfaiye istasyonuna daha ihtiyaç olduğu ve itfaiye istasyonlarının planlanmasına yönelik olarak Mekânsal Planlar Yapım Yönetmeliğinde düzenlemeler yapılması gerektiği sonuçlarına varılmıştır.

Anahtar Sözcükler

İtfaiye İstasyonu, Yer Seçimi, Yedek Çift Kapsama Yaklaşımı

\section{Determining The Need for Fire Stations by Backup Double Covering Approach and Location Selection: The Case of Trabzon City}

\begin{abstract}
Fire stations are emergency service units that serve for the security of lives and property in urban areas. It is critical for public safety to ensure the highest level of service ensuring a prompt response to the need. However, the land development legislation does not stipulate any provision with regard to the planning of fire stations and the number, size and location of the fire stations will be decided depending on the discretion of respective municipality. But the literature on the planning of fire stations recommends that fire stations must be planned for the entirety of the city based on a set of criteria including response time, coverage area, population density and etc. The objective of this study is to determine the minimum number of fire stations which can serve to the entirety of the planning area within a response time of 5 minutes and that also cover a second fire station as a backup to access within 5, 8, 10 or 15 minutes of response time according the fire risk class of the neighbourhood as indicated in the literature as well as to determine suitable publicly owned plots for such stations based on the master development plan in force. The area selected for this study is that located within the Ortahisar master development plan of the central district of Trabzon. This study will contribute to the determination of the fire station need of the city and site selection process. The findings of this study indicate that the existing fire station must be preserved at its current location, and that two new fire stations are needed which should be situated at eastern and western parts of the city, and also that the Regulation on Production of Spatial Plans must be amended to cover planning of the fire stations.
\end{abstract}

$\underline{\text { Keywords }}$

Fire Stations, Location Selection, Backup Double Covering Approach

\section{Giriş}

Yangınlar, Osmanlı ve erken Cumhuriyet dönemlerinde mekânsal planlamaya yön veren ve imar ile ilgili yasalarının çıkarılmasına vesile olan en önemli olgulardan biridir (Özgür ve Azaklı 2001). Osmanlı döneminde binalar birbirine çok yakın/bitişik bir biçimde ve ahşap malzeme ile inşa edildiğinden İstanbul' da çok büyük yangınlar yaşanmıştır. Örneğin, 19. Yüzyılda İstanbul'da yangınlarda yanan bina sayıları ve semtler: 1865 yılında Hocapaşa-Eminönü-Kumkapı: 1.007 , 1865 yılında Kumkapı ve Bali Paşa Yokuşu: 1.903, 1871 yılında Beyoğlu-Taksim-Galatasaray: $3.000,1890$ yılında Pendik: 1.200, 1911 yılında Çırçır-Fatih: 1.500, 1911 yılında Aksaray-Boğaziçi: 2.400, 1915 yılında Cihangir: 1.325, 
1918 yılında Cibali-Fatih-Altımermer: 7.500'dır. 1918 yılında İstanbul'da yanan toplam bina sayıs1 8.480'dir (Ersoy 2017). İlk İmar Kanunu olan 1882 tarihli Ebniye Kanununun (Binalar Kanunu) birçok maddesi yangınlara ilişkindir (Ersoy 2017). Tanzimat Dönemi ve erken Cumhuriyet dönemindeki yasal düzenlemelerde ağırlıklı olarak yangını önlemeye yönelik hükümlere yer verilmiş ve büyük yangınlardan sonra yangın yerlerinin düzenlenmesine ilişkin mevzi planlar hazırlanmıştır (Tekeli 1980). Geçmişte, büyük yangınlar mevcut kentsel dokuda büyük tahribatlara neden olmuş ve kent morfolojisini etkileyen önemli bir unsur olmuştur.

Günümüzde, itfaiye kamu güvenliğini sağlayan kamu kurum ve kuruluşlarından biridir. Bu nedenle acil müdahale gerektiren yangın, afet, kaza vb. durumlarda hizmete ihtiyaç duyan kişiye ya da bölgeye kısa sürede ulaşım kamu güvenliği açısından çok önemlidir (Çatay vd. 2008; Çatay 2011). Yapılaşmış kentsel alanda can ve mal güvenliği için acil durum hizmetleri, ihtiyaca hızlı yanıt verecek şekilde yüksek hizmet düzeyi ile sunulmalıdır (Selim ve Özkarahan 2003; Aktaş vd. 2011).

Ülkemizde mekânsal planların yapımına ve uygulanmasına ilişkin usul ve esaslar yürürlükteki Mekânsal Planlar Yapım Yönetmeliği’nde (URL-1 2014) belirlenmiştir. Bu yönetmelikte kentsel sosyal ve teknik altyapı alanlarına ilişkin standartlar tanımlanmıştır. Anılan yönetmeliğin 5/a maddesinde belediyelerin görev ve sorumlulukları kapsamındaki: İtfaiye, acil yardım ve kurtarma, ulaşıma yönelik transfer istasyonu, araç ve makine parkı, bakım ve ikmal istasyonu, garaj ve triyaj alanları, belediye depoları, asfalt tesisi, atık işleme tesisi, zabıta birimleri, mezbaha, ekmek üretim tesisi, pazar yeri ile idari, sosyal ve kültürel merkez vb. hizmet birimleri "belediye hizmet alanı" olarak tanımlanmış ve imar planlarında tüm bu hizmetlerin "belediye hizmet alanı" olarak planlanması emredilmiştir. Bu tanımda birbirinden çok farklı yer seçim ilkelerine sahip hizmetlerin tek bir arazi kullanım türü olarak planlanması ve gösterilmesi yönetmeliğe uygun olsa da planlama ilkelerine ve tekniklerine uygun değildir; çünkü itfaiye istasyonlarının daha genel bir arazi kullanım türü içinde planlanması bütünleşik bir hizmet ağının oluşmasını ve kişi başına standart itfaiye alanı planlanmasını engellemektedir. Diğer taraftan günümüzde yürürlükte olan Belediye İtfaiye Yönetmeliği de (URL-2 2006) kentsel düzeyde itfaiye istasyonlarının planlanması konusunda yetersiz kalmaktadır; çünkü bu yönetmelik, yalnızca belediye itfaiye teşkilâtının kuruluş, görev, yetki ve sorumluluklarını, itfaiye memurlarının niteliklerini, görevde yükselme ve mesleki eğitimlerini, kıyafetlerini, kullanacakları araç, teçhizat ve malzeme ile denetim usul ve esaslarını düzenlemektedir. Her iki yönetmelikte de kentsel düzeyde itfaiye istasyonlarının planlanması ve yer seçimine yönelik herhangi bir hükme yer verilmediğinden, kentteki itfaiye istasyonlarının sayısına, büyüklüklerine ve konumlarına ilişkin mekânsal kararlar, imar planında uygulamadan sorumlu belediyenin ve planlama ekibinin takdirine bırakılmıştır.

İtfaiye istasyonlarının planlaması ve yer seçimi ile ilgili literatür incelendiğinde; matematiksel programlama, çok ölçütlü karar destek sistemleri ve performans değerlendirmeye yönelik çalışmaların yapıldığı görülmektedir (Hacıoğlu 2010). Matematiksel programlamada itfaiye istasyonlarının planlanmasında iki temel yaklaşım vardır. Birinci yaklaşım, Toregas vd. (1971) tarafından önerilen Küme Kapsama Modelidir. Bu modelin amacı tüm bölgeleri belirli bir hizmet seviyesinde kapsayacak şekilde minimum istasyon sayısını belirlemektir. Aktaş vd. (2011) İstanbul itfaiyesinin sahip olması gereken itfaiye istasyonu sayısını belirlemek için yeni bir Küme Kapsama Modeli önermişlerdir. Önerilen bu model, bir tamsayı programlaması olup amaç fonksiyonu tüm mahallelerin beş dakikada hizmet görebilecek şekilde itfaiye istasyonu sayısını en aza indirmektedir. Kısıtlar ise tüm mahallelerin beş dakika tepki süresi içinde en az bir itfaiye istasyonu tarafından hizmet görmesini sağlamaktır. İkinci yaklaşım ise Church ve ReVelle (1974) tarafından geliştirilen Enbüyük Kapsama Modelidir. Bu modelin amacı belirli bir istasyon sayısı kısıtı altında, kapsanan bölge sayısını enbüyüklemektir (Çatay vd. 2008; Çatay 2011). Erden ve Coşkun (2011) çok ölçütlü karar destek sistemlerinden Analitik Hiyerarşi Yöntemi (AHY) ile Coğrafi Bilgi Sistemlerini (CBS) İstanbul'da itfaiye istasyonlarının yer seçiminde kullanmışlardır. AHY itfaiye istasyonlarının yer seçiminde önemli olan ölçütlerin ağırlıklarının saptanmasında, CBS ise ölçütlere ait mekânsal verilerin analizinde kullanılmıştır.

Kentsel alanda mevcut istasyonların performansını ölçmeye ve ihtiyaç duyulan istasyon yerlerini belirlemeye yönelik farklı yöntemlerle çalışmalar yapılmıştır. Hacıoğlu (2010) tez çalışmasında literatürde yer alan mekânsal ölçütlere Türkiye'deki itfaiye istasyonları ile ilgili mevzuatta hangi düzeyde yer verildiğini araştırmıştır. Bu çalışmada, literatürde itfaiye tesislerinin yer seçimi ve tasarım ölçütlerinin büyük-orta-küçük ölçeklerde belirlendiği, buna karşın ülkemizdeki yasal araçların yetersiz ve yüzeysel olduğu ve itfaiye istasyonlarının kentsel alanda yer seçimi ve tasarımına ilişkin sürecin öznel deneyimlerle yürütüldüğü sonuçlarına varılmıştır. Aktaş vd. (2013) ile KC vd. (2018a, 2018b) gelecek nüfus tahminine göre ihtiyaç duyulacak yeni itfaiye istasyonlarının alternatif yerlerini belirlemeye yönelik çalışmalar yapmışlardır. Sisman (2015) Samsun kent merkezinde 2013 yılında gerçekleşen 1014 yangın ve kurtarma olaylarını CBS ile sayısallaştırarak mahallelerin risk haritalarını hazırlamış ve itfaiye istasyonlarının konumlarını ağ analizi uygulamalarıyla irdelemiştir. Kara (2018) Artvin il merkezinde 2013-2017 yılları arasında meydana gelen bina yangınlarını incelemiştir. Bina yangınları türlerine, yanan yerin inşa malzemesine ve yanma derecesine göre sınıflanmış, meydana gelen kayıplar ve maddi zarar ile yangın çıkış nedenleri kamu ve özel binalar olarak iki kategoride incelenmiştir. Ölmez ve Geçen (2018) Antakya'da 2017 yılında meydana gelen yangınların zamansal ve mekânsal dağılışını incelemiştir.

İtfaiye hizmetlerinin imar planlarında uluslararası standartlara ve yer seçim ilkelerine uygun planlanması gerekmektedir. İtfaiye istasyonlarının planlamasına ilişkin literatür incelendiğinde, en önemli ölçütlerin tepki süresi, kapsama alanı ve nüfus olduğu görülmektedir (Selim ve Özkarahan 2003; Aktaş vd. 2011; Hacığlu 2010). 
Tepki/yanıt süresi, üniteler acil olaya giderken başlar ve üniteler sahneye vardığında sona erer. Sisman (2015) 8 dakikalık müdahale süresinin ilk 2 dakikasının çağrının alınması, hazırlık ve çıkış, son 1 dakikasının olay yerinde müdahaleye hazırlık süresi ve geriye kalan 5 dakikalık süreyi de ulaşım süresi olarak belirlemiştir. Habibi vd. (2008) nüfus yoğunluğu ve arazi kullanımlarını göz önünde bulundurarak 3 ile 5 dakika arasında bir tepki süresi önermişlerdir. Literatür araştırması sonucunda, kentsel itfaiye istasyonları için 5 dakikalık tepki süresinin hedeflenen bir tepki süresi olduğu görülmektedir. Kapsama alanı, itfaiyenin hareket veya sorumluluk bölgesi veya müdahale alanı olarak tanımlanmaktadır (Wright 1999; Habibi vd. 2008). Diğer bir ölçüt olan nüfus ise kiși başına planlanması gereken itfaiye alanı büyüklüğünü ifade etmektedir. Hacıŏlu (2010) itfaiye istasyonlarına ilişkin yaptığ literatür taramasında, itfaiye istasyonun kapsama alanının (hizmet) yarıçapının 0,5-8,5 km arasında değiştiğini ve kişi başına 0,01 ile $0,10 \mathrm{~m}^{2}$ arasında itfaiye alanı önerildiğini tespit etmiştir.

Tepki süresi ve kapsama alanı ölçütlerini kullanan yöntemlerden biri de Yedek Çift Kapsama Modelidir (Çatay vd. 2008; Çatay 2011). Çatay (2011) itfaiye istasyonlarının yer seçiminde yangın risk faktörüne dayalı Çoklu Kapsama Modelini İstanbul'da kullanmıştır. Bu model, bir matematiksel programlama olup kentsel alan içindeki tüm mahallelere önceden belirlenen tepki süresi içinde bir ana istasyon tarafından erişilmesini ve mahallenin risk sınıfına göre ikinci ve hatta üçüncü bir yedek itfaiye istasyon tarafından kapsanmasını amaçlamaktadır. Programlamadaki amaç fonksiyonu, belirlenen istasyon kısıtı altında kapsanan bölge sayısının enbüyüklenmesidir.

Bu çalışmanın amacı, Yedek Çift Kapsama yaklaşımı ile tüm planlama alanı içinde yer alan her bir mahalleye 5 dakika tepki süresi içinde hizmet verilebilecek ve mahallenin yangın risk sınıfına göre literatürdeki 5, 8, 10, 15 dakika erişim süreleri içinde ikinci bir itfaiye istasyonunun yedek kapsamında olacak şekilde en az itfaiye istasyon sayısını ve bu istasyonlara uygun kamusal alanları yürürlükteki nazım imar planında belirlemektir. Bu bağlamda bu çalışma hem mevcut kentsel yerleşim alanını hem de 2040 yılı hedef alınarak hazırlanan yürürlükteki nazım imar planındaki itfaiye istasyonu ihtiyacına yöneliktir. Çalışma alanı olarak Ortahisar imar planı sınırları seçilmiştir. Çalışma Ortahisar ilçesi sınırları içinde itfaiye istasyonlarının mekânsal gereksinimlerinin belirlenmesine, itfaiye istasyon ağ sisteminin oluşturulmasına ve itfaiye istasyon yerlerinin yer seçimi sürecine katkı sağlayacaktır.

\section{Materyal ve Yöntem}

Çalışma alanı, Trabzon İli, Ortahisar İlçesinin yürürlükteki nazım imar planı sınırlarını kapsayan 58 mahalleden oluşmaktadır (Şekil 1). 2012 yılında yasalaşan 6360 sayılı Kanun (URL-3 2012) ile tüm il sınırlarını kapsayan Trabzon Büyükşehir Belediyesi ve tüm merkez ilçeyi kapsayan Ortahisar Belediyesi kurulmuştur. Doğu Karadeniz Bölgesinin bölge merkezi olan Trabzon İlinin, merkezi ilçesi Ortahisar'dır. Valilik ile kamu kuruluşlarının ve özel sektör firmalarının bölge müdürlükleri genelde Ortahisar'da yer almaktadır. 2019 yılı TÜİK (2019) verilerine göre ilçenin mevcut nüfusu 328.457 ve yürürlükteki nazım imar planının 2040 yılına ait nüfus projeksiyonu 800.000 kişidir (SPO 2020).

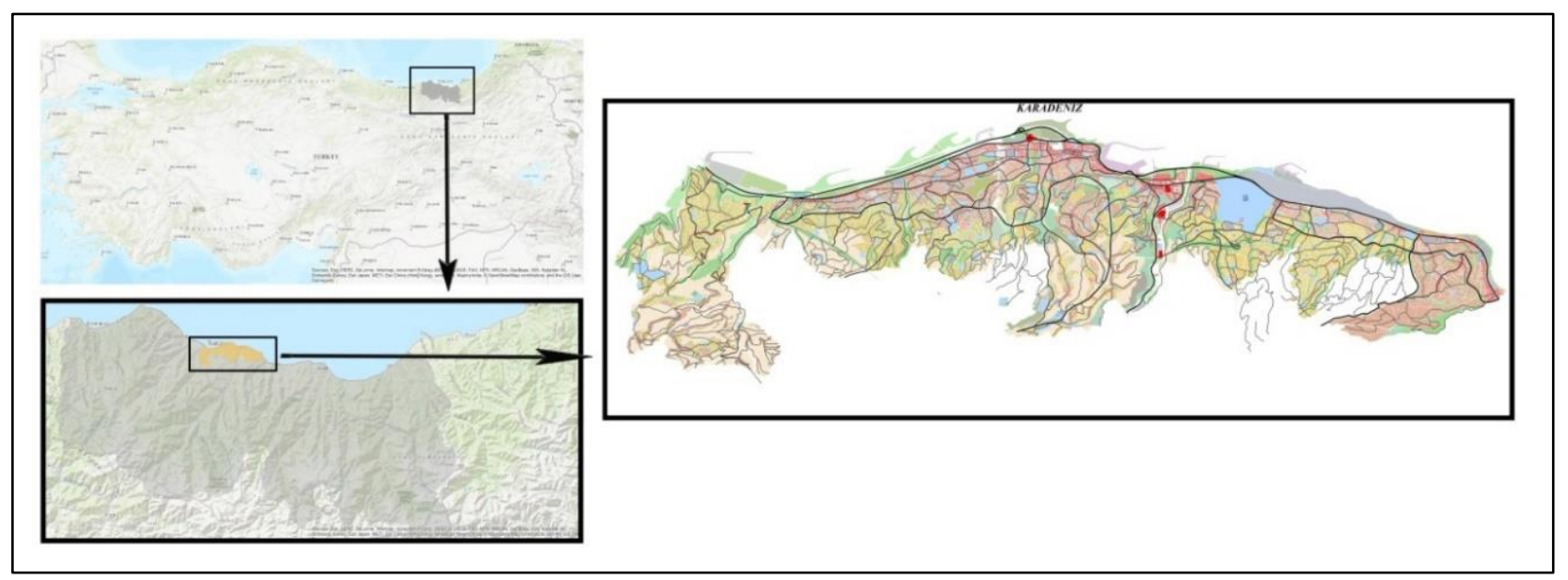

Şekil 1: Çalışma alanının konumu

Çalışma alanı içinde yalnızca Moloz mevkiinde 7 gün 24 saat hizmet veren ve tam teçhizatlı bir adet itfaiye istasyonu yer almaktadır. Bunun yanında, Değirmendere terminal alanı içinde sabah 9 akşam 21 saatleri arasında bir itfaiye aracının ve itfaiye personelinin bekletildiği belediye yetkilileri tarafından dile getirilmiştir. Ancak Değirmendere mevkiindeki itfaiye aracı ve personel 7 gün 24 saat hizmet vermediğinden ve düzenli ve planlı bir itfaiye istasyonu olmadığından yangın risk haritalarının hazırlanmasında ve önerilerin geliştirilmesinde dikkate alınmamıştır. Tüm Ortahisar ilçesine hizmet eden $4.471 \mathrm{~m}^{2}$ büyüklüğündeki mevcut itfaiye istasyon alanı, 20.02.2018 tarih ve 962 sayılı Trabzon Büyükşehir Belediye Meclis kararı ile onanan 1/5.000 ölçekli Revizyon+İlave Nazım İmar Planında park alanı (yeşil alan) planlanmıştır. 
Revizyon+İlave Nazım İmar Planın kapsadığı toplam alan 5129 ha ve BHA olarak planlanan alan 7,2 ha'dır. Yürürlükteki bu nazım imar planında çok farklı boyutlarda 21 adet belediye hizmet alanı (BHA) planlanmış olup planlama alanının yüzde 0.14'ü oluşturmaktadır. Bunların bir kısmı hâlihazırda Trabzon Büyükşsehir ve Ortahisar Belediyelerinin belediye hizmetlerini karşılayan mevcut, bir kısmı ise imar planında önerilmiş BHA’lardır. İmar planında kişi başına 0.9 m2 BHA planlanmış olup planın projeksiyon nüfusu ve bu nüfusun belediye hizmet ihtiyaçları göz önünde bulundurulduğunda planlanan BHA alanı yetersizdir.

$\mathrm{Bu}$ çalışmada dört aşamalı bir süreç izlenmiştir. Birinci aşamada, geçmiş yıllardaki yangın ve kurtarma verileri kullanılarak mahalleler bazında risk haritası hazırlanmıştır. Mahalleler yer aldıkları risk sınıflarına göre farklı sürelerde ulaşım gereksinimine sahiptir. "Çok riskli," "riskli," "orta riskli" ve "az riskli” olmak üzere dört risk sınıfı tanımlanmış ve her bir mahallenin çıkan yangın sayısına göre risk sınıfı belirlenmiştir (Çatay 2011). Risk harita verilerinin hazırlanmasında Trabzon Büyükşehir Belediyesi İtfaiye Dairesi Başkanlığı'nın 2017 yılı yangın verileri kullanılmıştır. 2017 yılında çalışma alanında 432 adet yangın ve kurtarma olayı gerçekleşmiştir. Bu yangın ve kurtarma olayları CBS yazılımı olan ArcGIS ${ }^{\odot}$ ortamında sayısallaştırılmış ve öznitelik bilgileri CBS veri tabanına girilmişstir. Veri tabanına girilen bilgiler CBS kullanılarak analiz edilmiş ve her bir mahallenin risk sınıfı belirlenmiştir.

İkinci aşamada, yürürlükteki 1/5000 ölçekli nazım imar planındaki yollar ArcGIS ${ }^{\odot}$ paket programının Hizmet Alanı (Service Area) modülü kullanılarak bütünleşik yol ağı sitemi oluşturulmuştur. Yol bilgileri, üç ana grupta toplanmıştır: ana yollar, toplayıcı yollar ve yerel yollar. Aktaş vd. (2011) varsaydığı gibi yolların hızları, ana yollar için $80 \mathrm{~km} / \mathrm{saat}$, toplayıcı yollar için $50 \mathrm{~km} /$ saat ve yerel yollar için $20 \mathrm{~km} /$ saat kabul edilmiş ve öznitelik verisi CBS veri tabanına girilmiştir. Bu yol ağı sistemi ile mevcut yangın itfaiye istasyonunun literatürde öngörülen beş dakika tepki süresi içinde erişebildiği mahalleler ile 8,10 ve 15 dakikada erişilen mahalleler tespit edilmiştir.

Üçüncü aşamada, yürürlükteki nazım imar planında belediye hizmet alanı veya kamusal alan planlanmış alanlardan itfaiye istasyonuna uygun olabilecek alanlar incelenmiş ve alternatif alanlar seçilmiştir. Alternatifler belirlenirken karayolu erişiminin en önemli ölçüt olduğu dikkate alınarak; ulaşım sistemi tek başına, ulaşım ile bir diğer ölçütün birlikte değerlendirildiği ulaşım-eğitim tesisleri, ulaşım-kümelenme, ulaşım-doğal alanlar ve ulaşım-BHA şeklinde analizler hazırlanarak her bir değerlendirme için alternatif yerler belirlenmiştir. Bu analizler çakıştırılarak en fazla değerlendirmede alternatif yer olarak öne çıkan dört yer detaylı incelenmek için seçilmiştir.

Dördüncü aşamada, her mahalle 5 dakika tepki süresi içinde bir ana itfaiye istasyonu tarafından kapsanacak ve mahallenin risk sınıfına göre de 5, 8, 10 ve 15 dakika tepki süresinde yedek bir itfaiye istasyonu tarafından kapsanacak şekilde itfaiye tesislerinin sayısı ve yerleri tespit edilmiştir. Çalışmada, itfaiye istasyonlarının yatırım ve işletme maliyetlerinin yüksek olduğu göz önünde bulundurularak toplam itfaiye istasyonu sayısının en aza indirilmesi hedeflenmiştir.

\section{Bulgular ve Tartışma}

Mahalleler bazında oluşturulan risk haritasında mahallelerin; 4’ü (\%7) “çok riskli”, 17'si (\%30) “riskli”, 10’u (\%17) “orta riskli” ve 26’sı (\%46) “az riskli” sınıfında olduğu tespit edilmiştir (Şekil 2). Ticaret alanlarının yer aldığı Pazarkapı, küçük sanayi sitesinin yer aldığı Değirmendere ve Sanayi mahalleleri ile konut alanlarının yer aldığı 2 Nolu Erdoğdu mahalleleri çok riskli, kent merkezi ve çeperinde yoğun yapılaşmasının olduğu mahalleler genellikle orta riskli, kentin çeperinde kısmen yapılaşmış mahalleler ise az riskli sınıfında yer almıştır.

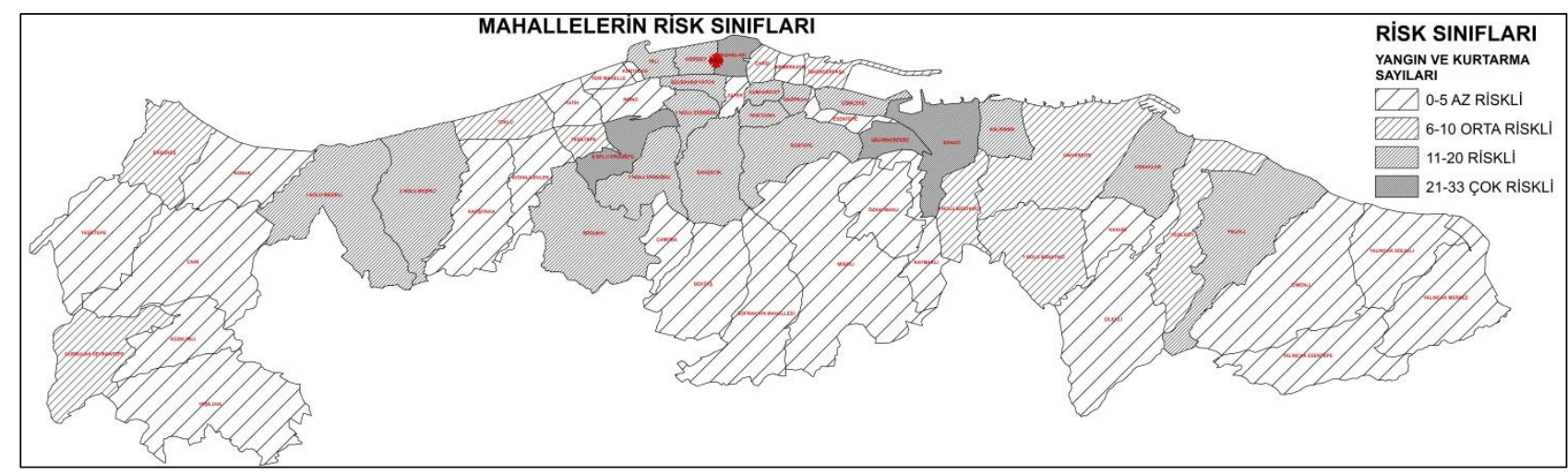

Şekil 2: Mahallelerin yangın risk sınıflaması

Çalışmanın ikinci aşamasında, yürürlükteki imar planındaki yollar ArcGIS ${ }^{\odot}$ programı kullanarak bütünleşik yol ağı sistemi oluşturulmuştur. Yürürlükteki imar planında, kuzeyde Karadeniz güneyde ani yükselen dağlar nedeniyle kentsel yerleşim dar sahil şeridinde doğrusal makro formda planlanmıştır. Ancak doğrusal kent makro formu güney-kuzey yönündeki dereler ve vadiler ile parçalandığından, kentsel yerleşim alanları genellikle sırtlar ve yamaçlar üzerinde planlanmıştır. Doğrusal kent makro formuna uygun olarak ana yollar doğu batı istikametinde planlanmıştır. 
Yürürlükteki nazım imar planı karayolu ağ sistemine göre mevcut itfaiye istasyonunun 5, 8, 10 ve 15 dakika tepki süresinde kapsadığı mahalleler belirlenmiştir (Şekil 3). Yedek Çift Kapsama yaklaşımında her mahallenin 5 dakika tepki süresi içinde bir ana itfaiye istasyonu tarafından kapsanması ve mahallenin risk sınıfına göre de 5, 8, 10 ve 15 dakika tepki süresinde yedek bir itfaiye istasyonu tarafından kapsanması gerekmektedir. Ancak mevcut itfaiye istasyonu, kentin doğusundaki Yalıncak-Merkez, Yalıncak-Gülyalı, Yalıncak-Esentepe ve Çimenli mahallelerinin tamamı ile Pelitli, Yeşilköy ve Çilekli mahallelerinin bir kısmı; kentin batısındaki Gürbulak ve Seyrantepe mahallelerinin tamamı ile Yeşiltepe, Cami, Güzelyalı ve Yeșilova mahallelerinin bir kısmına 5 dakikalık tepki süresinde erișememektedir.

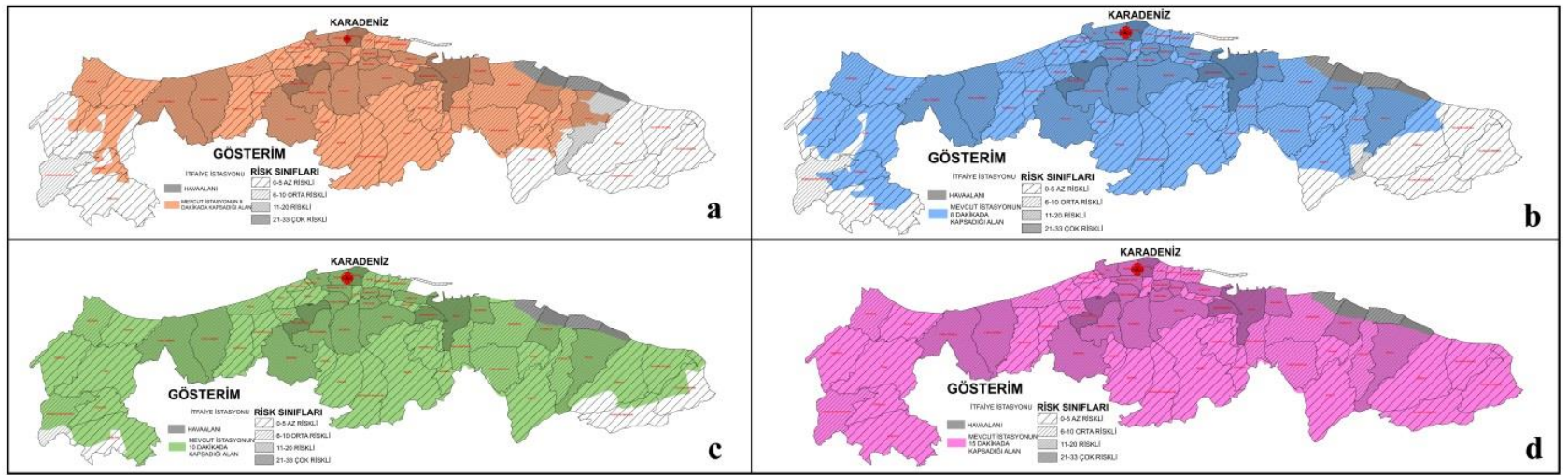

Şekil 3: Mevcut itfaiye istasyonunun 5, 8, 10 ve 15 dakika tepki süresinde kapsadığı mahalleler

Yedek Çift Kapsama Modeli yaklaşımına göre çok riskli sınıfında yer alan bir bölgenin kapsanmış sayılabilmesi için 5 dakikada iki farklı istasyon tarafından kapsanması gerekmektedir (Şekil 3/a). Çünkü çok riskli sınıf acil talebi yüksek olan mahalleleri ifade etmektedir. Bu mahalleler 2 Nolu Erdoğdu, Pazarkapı, Değirmendere ve Sanayi mahalleleridir. Mevcut durumda çok riskli mahalleler mevcut istasyon tarafından 5 dakikada hizmet verilmektedir. Ne var ki, kentte ikinci bir istasyon olmadığından kentin tamamında yedek kapsama yoktur.

Mevcut itfaiye istasyonu, 8 dakika tepki süresinde kentin doğusunda Yalıncak Merkez, Yalıncak Gülyalı, Yalıncak Esentepe mahallelerin tamamı ile Çimenli, Pelitli, Yeşilköy mahallelerinin güney kısmı; kentin batısında, Yeşiltepe, Cami, Güzelyalı, Gürbulak-Seyrantepe ve Yeşilova mahallelerinin bir kısmını kapsamamaktadır (Şekil 3/b). Yedek Çift Kapsama yaklaşımı doğrultusunda riskli sınıfındaki bir bölgenin kapsanmış sayılabilmesi için bir istasyon tarafından 5 dakikalık tepki süresi içinde kapsanması ve 8 dakika tepki süresi içinde ikinci bir istasyon tarafından da kapsanması gerekmektedir.

Mevcut itfaiye istasyonu, 10 dakika tepki süresinde kentin doğusunda Yalıncak-Merkez, Yalıncak-Esentepe ve Çimenli mahallelerinin bir kısmı ile kentin batısında Gürbulak-Seyrantepe ve Yeşilova mahallelerinin bir kısmını kapsamamaktadır (Şekil 3/c). Yedek Çift Kapsama model yaklaşımı doğrultusunda orta riskli bir bölgenin kapsanmış sayılabilmesi için bir istasyon tarafından 5 dakikalık tepki süresi içinde kapsanması ve 10 dakika tepki süresi içinde ikinci bir istasyon tarafindan da kapsanması gerekmektedir.

Mevcut itfaiye istasyonu, 15 dakika tepki süresinde imar planı sınırları içindeki tüm mahalleler kapsamaktadır (Şekil 3/d). Az riskli sınıfında yer alan bir bölgenin kapsanmış sayılabilmesi için 5 dakikalık tepki süresi içinde bir istasyon tarafından kapsanması ve en fazla 15 dakika içinde ikinci bir istasyon tarafından kapsanması gerekmektedir. Mevcut itfaiye istasyonu az riskli mahallelerin tümüne 5 dakika tepki süresince erişememektedir ve en fazla 15 dakikalık tepki süresi içinde ikinci bir istasyon tarafından da kapsanması gerekmektedir.

Çalışmanın üçüncü aşamasında, yürürlükteki nazım imar planında belediye hizmet alanı veya kamusal alan planlanmış alanlardan itfaiye istasyonuna uygun olabilecek alanlar incelenmiş ve alternatif alanlar belirlenmiştir (Şekil 4).

Alternatifler belirlenirken karayolu erişiminin en önemli kriter olduğu dikkate alınarak ulaşım sistemi tek başına ve ulaşım-eğitim tesisleri, ulaşım-kümelenme ve ulaşım-doğal alanlar, ulaşım-BHA şeklinde ulaşım ile bir diğer kriter birlikte değerlendirilerek her bir değerlendirme için alternatif yerler belirlenmiştir. Yalnızca ulaşım sistemi dikkate alındığında 18; ulaşım-eğitim değerlendirmesinde 7; ulaşım-doğal yapı değerlendirmesinde 13; ulaşım-kümelenme değerlendirmesinde 4; ulaşım-BHA değerlendirmesinde 2 alternatif yer tespit edilmiştir. Her bir değerlendirmedeki alternatifler çakıştırılarak her bir alternatifin kaç değerlendirmede uygun olup olmadığı incelenmiştir. Bazı alternatifler 2 değerlendirmede uygun iken bazı alternatifler 3-4 değerlendirmede uygundur. Çok sayıda değerlendirme ölçütünde uygun olan dört alternatif seçilmiştir (Şekil 5). 


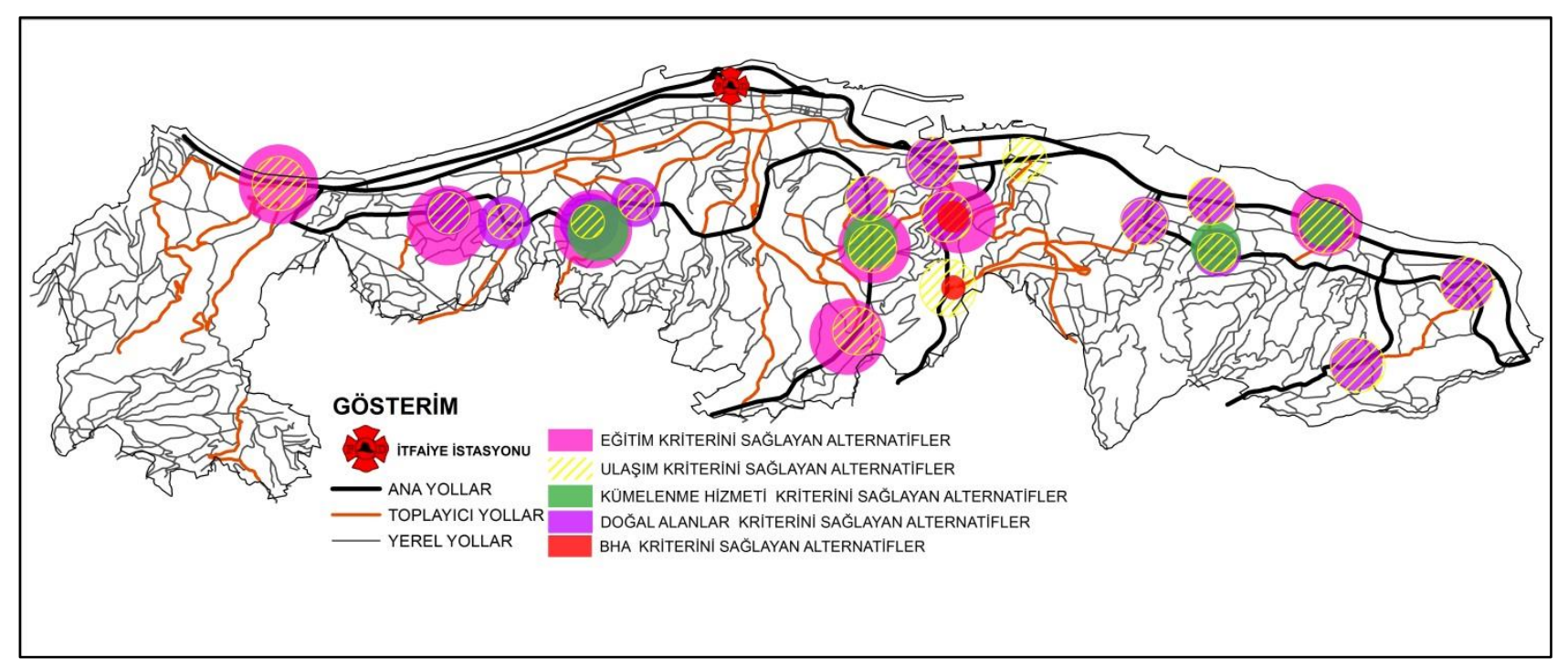

Şekil 4: Farklı değerlendirme ölçütlerine göre belirlenen alternatif yerler

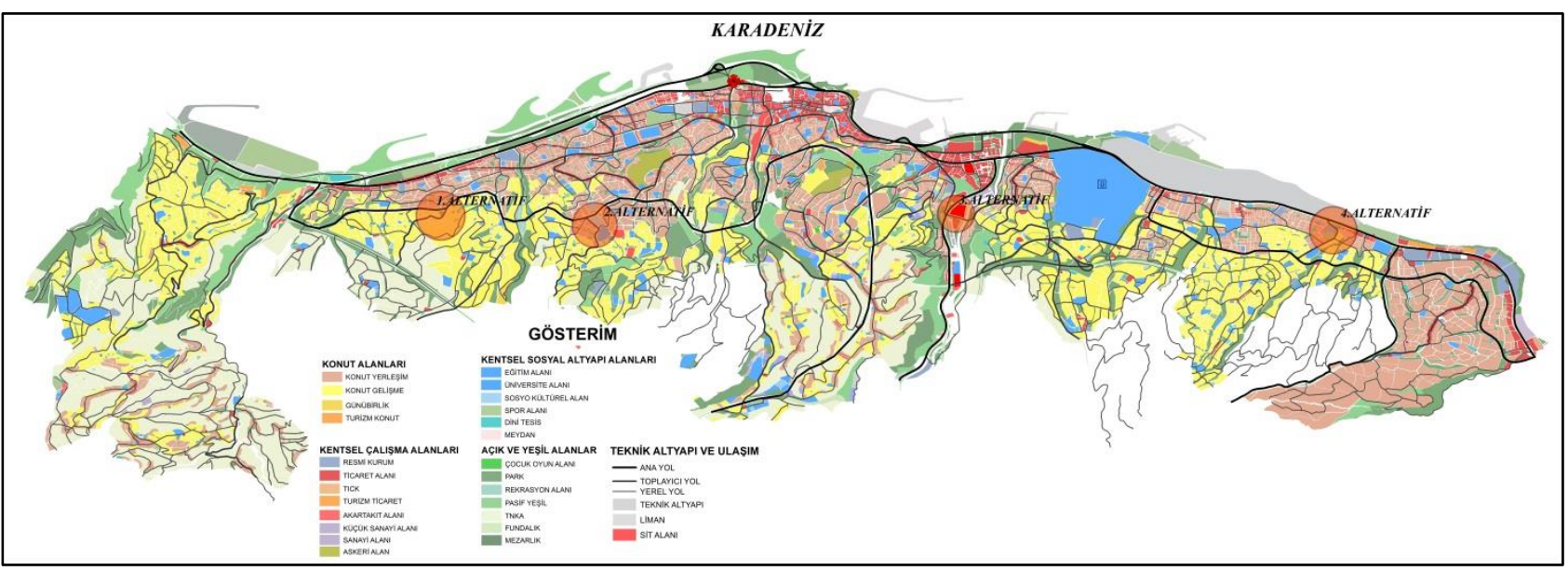

Şekil 5: Itfaiye istasyonuna uygun seçilen alternatif yerler ve yürürlükteki imar planı

Son aşamada seçilen dört alternatif detaylı bir şekilde incelenmiş ve karşılaştırılmıştır (Şekil 6). Alternatifler, mevcut itfaiye istasyonunun beş dakika tepki süresi içinde erişemediği mahallelere bu sürede erişmesi ve diğer mahallelerin risk sınıfına göre yedek kapsama sağlaması ile Hacıŏlu'nun (2010) literatür taramasından ve alan çalışmasından elde ettiği itfaiye istasyonu yer seçimi kriterlerine göre yapılmıştır. Bu kriterlere göre itfaiye istasyonları:

- Otoyollar, tüneller, transit yollar ve çok yoğun arterler üzerinde olmamalıdır.

- Herhangi bir trafik tıkanıklığından kaçınmak için 22 m'den daha geniş veya alt arteriyel yola doğrudan ve hızlı erişime sahip olmalıdır.

- En az iki alternatif erişim noktasıyla kolay giriş ve çıkış sağlayacağından köşe parsel olabilir.

- En yakın istasyonlar arasındaki mesafe ekonomik ve güvenlik sorunları dikkate alınarak 1-9 km arasında olmalıdır.

- Alanı 3.000 - $6.000 \mathrm{~m}^{2}$ büyüklüğünde ve mümkünse düz, değilse az eğimli bir araziye sahip olmalıdır.

- Polis, acil sağlık servisi vb. acil servis birimlerine yakın olarak kümelenme hizmeti vermelidir.

- Tepki süresinin artmasına neden olduğundan bahçeler, tarım arazileri, tepeler vb. önleyici faktörlerle bitişik ya da yakın yerleştirilmemelidir.

- Güvenlik problemlerinden kaçınmak, eğitim faaliyetlerini sekteye uğratmamak ve öğrencilerin davranışlarını olumsuz yönde etkilememek için eğitim tesislerine yakın olmamalıdır.

Değerlendirmeler sonucunda, bütün alternatiflerin 20-25 m genişliğindeki ana yola doğrudan erişime sahip olduğu ve tarımsal niteliği korunacak alan ile eğitim alanlarına uzak olduğu tespit edilmiştir.

Birinci alternatif bir çok kriter açısından uygun olmasına karşın, arsası asgari büyüklüğün altındadır $\left(2.446 \mathrm{~m}^{2}\right)$ ve diğer acil servis hizmetlerine yakın değildir.

İkinci alternatif bütün değerlendirme kriterleri açısından olumlu özelliklere sahiptir. Mevcut itfaiye istasyonunun 5 dakika tepki süresinde erişemediği güneybatıda kalan mahalleleri kapsamakta, çok riskli mahallelere 5 dakika tepki süresi içinde yedek kapsama sağlamakta ve güneyinde sağlık alanına yakındır. 
Ancak yürürlükteki imar planında bu alan "sosyo-kültürel alan” planlıdır. Bu alanın itfaiye istasyonuna dönüştürülmesi için imar planında değişikliği yapılmalı ve yakın çevrede kaldırılan sosyo-kültürel alanı büyüklüğünde başka bir alanının sosyo-kültürel alan olarak planlanması gerekmektedir.

Üçüncü alternatif birçok değerlendirme kriteri açısından olumludur. Mevcut itfaiye istasyonunun 5 dakika tepki süresi kapsamında erişemediği güneyde kalan mahallelere 5 dakika tepki süresi içinde erişilmesi, çok riskli mahallelere 5 dakika tepki süresi içinde yedek kapsama sağlaması ve mevcutta bu alanın BHA olması bu alternatifin avantajlarıdır.

Dördüncü alternatif birçok değerlendirme kriteri açısından olumlu özelliklere sahiptir. Mevcut itfaiye istasyonunun 5 dakika tepki süresi içinde erişemediği güneyde kalan mahallelere 5 dakika tepki süresinde erişmektedir. Ancak bu alternatif çok riskli olan 2 nolu Erdoğdu Mahallesine 5 dakika tepki süresinde yedek kapsama sağlayamamaktadır.

\begin{tabular}{|c|c|c|}
\hline & ALTERNATIF ISTASYONLARIN KAPSAMA ALANLARI & ÖZELLIKKLER-DEĞERLENDİRME \\
\hline 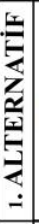 & & 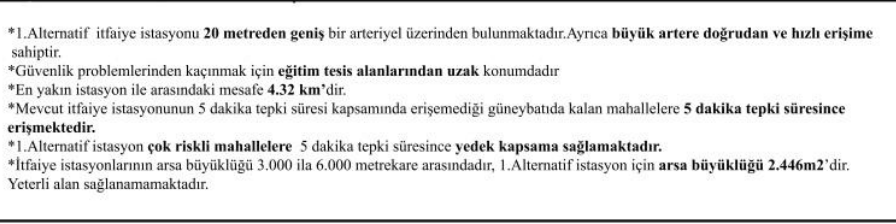 \\
\hline 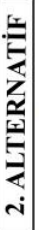 & & 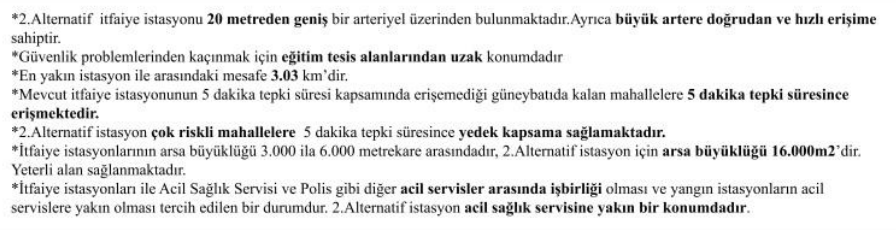 \\
\hline 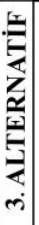 & & 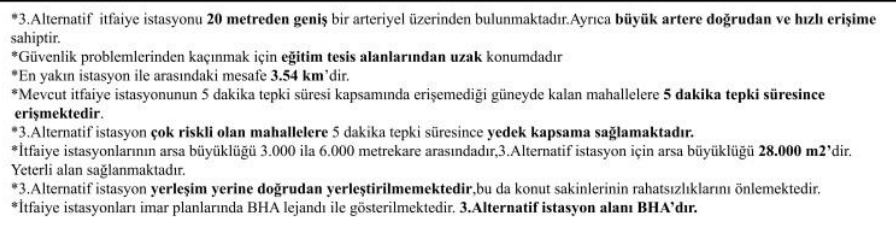 \\
\hline 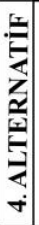 & 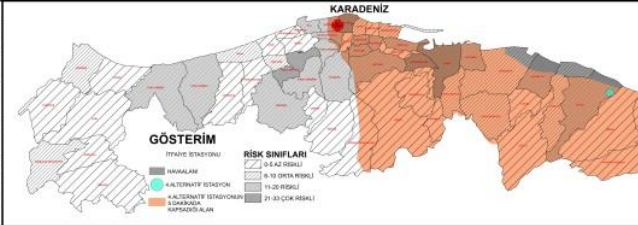 & 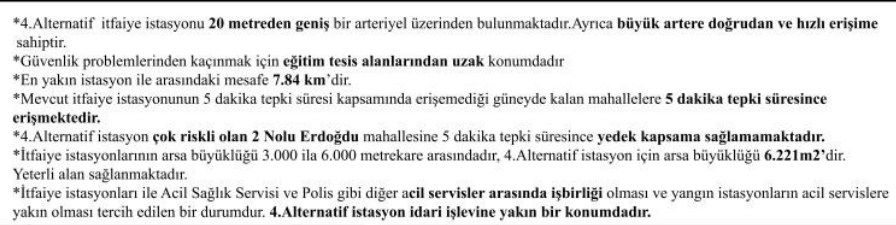 \\
\hline
\end{tabular}

Şekil 6: Alternatif yerlerin değerlendirmesi

Kentin doğrusal makro formu ve vadiler tarafından sık sık parçalanması, ulaşım mesafelerini ve tepki süresini artırmaktadır. Yapılan çalışma sonucunda, Moloz Mevkiindeki mevcut itfaiye istasyonunun yer seçiminin uygun olduğu ve devamının sağlanması gerektiği, bunun yanında kentin doğusunda ve batısında birer tane daha itfaiye istasyonuna ihtiyaç olduğu tespit edilmiştir. Alternatiflere yönelik yapılan değerlendirme sonucunda; birinci alternatif yeterli alan büyüklüğüne sahip olmadığından ve dördüncü alternatif çok riskli sınıfındaki 2 nolu Erdoğdu Mahallesine 5 dakika tepki süresi içinde yedek kapsama sağlamadığından uygun bulunmamıştır. İkinci alternatifin güneyi yürürlükteki imar planında sağlık alanı planlandığından acil sağlık birimine komşu olması, üçüncü alternatifin imar planında BHA planlı olması, ikinci ve üçüncü alternatiflerin seçilmesine neden olmuştur. Seçilen bu alternatifler, iki mahallenin güneyinde çok az bir alana hedeflenen sürede ulaşamamaktadır. Bu alanlar tarımsal niteliği korunacak alan planlı olduğundan çalışmada göz ardı edilmiştir.

\section{Sonuç}

Yangınlar can ve mal güvenliğini tehdit eden afetlerdir. Bu hizmetin yüksek hizmet kalitesi ile sunulması kamu güvenliği için zorunludur. Bunun için itfaiye istasyonlarının yeterli sayıda, konumda ve büyüklükte planlanması gerekmektedir. Ancak imar planlarını şekillendiren imar mevzuatında itfaiye istasyonlarının nasıl planlanacağına ilişkin hükme yer verilmemiş ve diğer birçok belediye hizmetleri gibi "Belediye Hizmet Alanı” içinde planlanması emredilmiştir. Diğer taraftan İtfaiye Yönetmeliğinde de (URL-2 2006) itfaiye istasyonlarının planlanması ve yer seçimine ilişkin herhangi bir hükme yer verilmemiştir. Bu bağlamda ülkemizde itfaiye istasyonlarının planlanması ve yer seçimi ilgili belediyenin takdirine bırakılmıştır.

Bu çalışmada Yedek Çift Kapsama Modeli ile Ortahisar imar planı sınırları içinde yer alan her bir mahalleye teknik açıdan uygun tepkime süreleri ve diğer yer seçimi ölçütleri çerçevesinde hizmet verilebilecek yedek itfaiye istasyonu/istasyonları için gerekli BHA’lar yürürlükteki nazım imar planında belirlenmiştir. 
Modelin nazım imar planı bütününde uygulanması çalısmayı özgün kılmaktadır. Çalışma, Ortahisar ilçesi sınırları içinde itfaiye istasyonlarının mekânsal gereksinimlerinin belirlenmesine ve yer seçimi sürecine katkı sağlayacaktır.

Yapılan alan çalışması sonucunda şu sonuçlara varılmıştır: (1) Var olan itfaiye tesisi alanı yürürlükteki imar planında park olarak planlanmıştır. Ancak bu alan kent merkezine yakınlığı, birden fazla ana arterin birbirine bağlandığı kavşak noktasında yer alması, yeterli alan büyüklüğüne sahip olması nedenleriyle bu alanın itfaiye alanı olarak kalması gerekmektedir. (2) Mevcut istasyon beş dakika tepki süresi içinde tüm çalışma alanına hizmet verememektedir. Ayrıca her bir mahallenin yangın risk sınıfına göre ana istasyon dışında başka bir istasyonun yedek kapsamında olması gerekmektedir. Hem dünya standardı olan beş dakika tepki süresi içinde tüm alanının kapsanması hem de mahallenin yangın risk sınıfına göre yedek istasyon tarafından kapsanması için kentin doğusunda ve batısında birer tane daha itfaiye istasyonuna ihtiyaç vardır. (3) Yürürlükteki imar planında kamusal alan olarak planlanmış alanlar incelenmiş, karşılaştırılmış ve bunlardan iki tanesi itfaiye istasyon yeri olarak seçilmiştir.

İtfaiye hizmetleri belediyeler tarafından sunulan bir hizmet olduğundan Mekânsal Planlar Yapım Yönetmeliğinde (Resmi Gazete 2014) "Belediye Hizmet Alanı” içinde tanımlanmış, ayrı bir gösterim ile planlanması istenmemiş ve herhangi bir standardı belirlenmemiştir. Oysa bu kentsel kullanım diğer belediye hizmetlerinden çok farklı olup, plan sınırları içinde tepki süresi, kapsama alanı ve nüfus ölçütleri dikkate alınarak planlanmasına ve "itfaiye istasyon alanı" gösteriminin eklenmesine ilişkin düzenlemelerin yönetmelikte yapılması gerekmektedir. Bu düzenlemenin yalnızca itfaiye istasyonlarına yönelik değil tüm acil servis hizmetlerini kapsayacak şekilde yapılmasında fayda vardır.

\section{Teşekkür}

Makale üzerinde yaptığı değerli yorum ve katkıları için KTÜ Emekli Öğretim Üyesi Prof. Dr. Saliha Erkonak Aydemir’e teşekkür ederiz.

\section{Kaynaklar}

Aktaş E., Özaydın Ö., Bozkaya B., Ülengin F., Önsel Ş., (2013), Optimizing fire station locations for the Istanbul metropolitan municipality, Interfaces, 43, 240-255.

Aktaş E., Özaydın Ö., Ülengin F., Önsel Ş., Ağaran B., (2011), Istanbul'da itfaiye istasyonu yerlerinin seçimi için yeni bir model, Endüstri Mühendisliğ Dergisi, 22(4), 2-12.

Church R.L., ReVelle C., (1974), The maximal covering location problem, Papers of the Regional Science Association, 32, 101-118.

Çatay B., (2011), Istanbul'da itfaiye istasyonu yer seçiminde risk faktörüne dayalı bir çoklu kapsama yaklaşımı, Endüstri Mühendisliği Dergisi, 22(2), 33-44.

Çatay B., Başar A, Ünlüyurt T., (2008), İstanbul'da acil yardım istasyonlarının yerlerinin planlanması, Endüstri Mühendisliği Dergisi, 19(4), 20-35.

Erden T., Çoşkun M.Z., (2011), Coğrafi bilgi sistemleri ve Analitik Hiyerarşi Yöntemi yardımıyla itfaiye istasyonu yer seçimi, HKMO 13. Türkiye Harita Bilimsel ve Teknik Kurultay1, 18-22 Nisan, Ankara. https://www.hkmo.org.tr/resimler/ekler/ 9f6168a7da07185_ek.pdf, [Erişim 23 Kasım 2020].

Ersoy M., (2017), Osmanlıdan günümüze imar ve yasalar, Ninova Yayınları, İstanbul, 280ss.

Habibi K., Lotfi S., Koohsari M.J., (2008), Spatial analysis of urban fire station locations by integrating AHP Model and IO Logic using GIS (A case study of zone 6 of Tehran), Journal of Applied Sciences, 8, 3302-3315.

Hacioğlu Ç., (2010), Spatial requirements of fire stations in urban areas: a case study of Ankara, Yüksek Lisans Tezi, Orta Doğu Teknik Üniversitesi, Ankara, Türkiye.

Kara İ.B., (2018), 2013-2017 yılları arasında Artvin il merkezinde meydana gelen bina yangınlarının incelenmesi, Doğal Afetler ve Çevre Dergisi, 4(2), 105-114.

KC K., Corcoran J., Chhetri P., (2018a), Spatial optimisation of fire service coverage: A case study of Brisbane, Australia Geogr Res, 56(3), 270-284.

KC K., Corcoran J., Chhetri P., (2018b), Measuring the spatial accessibility to fire stations using enhanced floating catchment method, Socio-Economic Planning Sciences, 69, 100673, doi: 10.1016/j.seps.2018.11.010.

Ölmez İ., Geçen R., (2018), Antakya'da (Hatay) 2017'de meydana gelen yangınların zamansal ve mekansal dağıllışı, TÜCAUM 30. Y1l Uluslararası Coğrafya Sempozyumu 3-6 Ekim, Ankara.

Özgür H., Azaklı S., (2001), Osmanlı'da yangınlar ve itfaiye hizmetleri, Gazi Üniversitesi İktisadi ve İdari Bilimler Fakültesi Dergisi, 3(1), 153-172.

Selim H., Özkarahan İ., (2003), Acil servis araçları yerleşiminin belirlenmesinde yeni bir model, Endüstri Mühendisliği, 14(1), $18-27$.

Sisman A., (2015), Yangın risk haritasının üretilmesi ve istasyonların konumlarının uygun yer analizi ile irdelenmesi, 6/2015, Valencia/İspanya, https://www.isites.info/PastConferences/ISITES2015/ISITES2015/papers/A14-ISITES2015ID74.pdf, [Erişim 20 Ağustos 2020].

SPO, (2020), Ortahisar ilçesi nazım imar planı inceleme-değerlendirme ve görüş raporu, http://www.spo.org.tr/resimler/ekler/ 7d85dbbb80476f0_ek.pdf?tipi=4\&turu=H\&sube=10, [Erişim 20 Ağustos 2020].

Tekeli İ., (1980), Türkiye'de kent planlamasının tarihsel kökenleri. T. Gök, (derl.) Türkiye'de imar planlaması, ODTÜ Mimarlık Fakültesi Yayını, Ankara.

Toregas C.R., Swain R., ReVelle C.S., Bergman L., (1971), The location of emergency service facilities, Operations Research, 19, $1363-1373$.

TÜIK, (2019), 2019 Yılı Adrese Dayalı Nüfus Kayıt Sistemi Sonuçları, Türkiye İstatistik Kurumu, https://biruni.tuik.gov.tr/medas/? $\mathrm{kn}=95 \&$ locale=tr, [Erişim 20 Ağustos 2020]. 
URL-1, (2014), Mekânsal Planlar Yapım Yönetmeliği, Resmi Gazete Tarih: 14.06.2014, Sayı: 29030, https://www.mevzuat.gov.tr/ mevzuat?MevzuatNo=19788\&MevzuatTur=7\&MevzuatTertip=5, [Erişim 20 Ağustos 2020].

URL-2, (2006), Belediye Itfaiye Yönetmeliği, Resmi Gazete Tarih: 21.10.2006, Sayı: 26326, https://www.mevzuat.gov.tr/File/ GeneratePdf?mevzuatNo=10713\&mevzuatTur=KurumVeKurulusYonetmeligi\&mevzuatTertip=5, [Erişim 20 Ağustos 2020].

URL-3, (2012), On Dört İlde Büyükşehir Belediyesi ve Yirmi Yedi İlçe Kurulması İle Bazı Kanun Ve Kanun Hükmünde Kararnamelerde Değişiklik Yapılmasına Dair Kanun, Resmi Gazete Tarih: 06.12.2012, Sayı: 28489, https://www.mevzuat.gov.tr/mevzuat? MevzuatNo=6360\&MevzuatTur=1\&MevzuatTertip=5, [Erişim 20 Ağustos 2020].

Wright M.S., (1999), Dwelling risk assessment toolkit, Entec UK Ltd., London. 